\title{
31. SYNTHESIS OF THE LEG 40 BIOSTRATIGRAPHY AND PALEONTOLOGY
}

\author{
Hans M. Bolli, Department of Geology, Swiss Federal Institute of Technology, Zürich, and University of Zürich, Switzerland
}

\section{INTRODUCTION}

Several groups of micro- and macrofossils have been investigated from the sections recovered from Leg 40 Sites 360 through 365 . The biostratigraphic/paleontological chapters in this volume indicated by ( ) and in the supplemental volume indicated by [ ] include the following papers: a paper by Proto Decima et al. (12) deals with the Cretaceous and Cenozoic calcareous nannoplankton, another by Bukry (13) is on the Cenozoic silicoflagellates and coccoliths. Four are on planktonic foraminifers: Caron (14) for the Cretaceous, Toumarkine (15) for the Paleogene and part of the Neogene, Jenkins (16) for the Neogene of Sites 360 and 362, and Jenkins [9] on the genus Guembelitria. Four contributions deal with benthic foraminifers: Scheibnerová (17) on the Lower Cretaceous, Beckmann (18) on the Upper Cretaceous, Proto Decima and Bolli (19) on the Paleogene, and Cameron (20) on the Neogene. Two radiolarian papers are included in this report: one by Foreman (22) on the Cretaceous, another by Pisias and Moore (23) on the Tertiary. The four chapters on palynomorphs include papers by McLachlan and Pieterse (24) and by Davey (25) on the Cretaceous of Site 361, by Morgan (26) on the Cretaceous of Site 364, and by Partridge (27) on the Tertiary of Site 365. In addition, a contribution by Brown [8] treats plant fragments from the Lower Cretaceous sapropels of Site 361. Bolli presents two papers, one (21) on Cretaceous and lower Paleocene Calcisphaerulidae from Site 363, and one [10] on calcareous spherules incertae sedis from the Lower Cretaceous of Site 363. Matsumoto [11] describes Inocerami, Wiedmann and Neugebauer [12] Lower Cretaceous ammonites from Sites 363 and 364, Schrader [13] opal phytoplankton, and Doyle et al. [14] Cretaceous and Tertiary ichthyoliths.

With this extensive coverage and documentation of different fossil groups it became possible to date the Leg 40 sediments with the best available accuracy and obtain further valuable information on the latitudinal and stratigraphical distribution of many taxa.

The sediments of Sites 360 and 361 in the Cape Basin, Sites 362 and 363 on Walvis Ridge, and Sites 364 and 365 in the Angola Basin contain faunas and floras ranging from boreal to tropical in character. The wide latitudinal range of the sites, from $36^{\circ} \mathrm{S}$ to $11^{\circ} \mathrm{S}$, therefore offered an excellent opportunity to study changes during the Cretaceous and Tertiary of the faunal/floral associations through time and space. In particular, the Tertiary planktonic foraminifers changed from predominantly cold water forms in the Cape Basin to mixed assemblages on Walvis Ridge and largely tropical forms in the Angola Basin. Both the boreal Austral-New Zealand and the tropical zonal schemes could be applied to the Tertiary of the Cape Basin, and also in part to the Walvis Ridge sections, for the first time allowing for a close correlation between these two zonal schemes in this general area. This overlap of cold- and warm-water faunal associations will prove of significance for the worldwide calibration and correlation of the two schemes which are largely based on different species.

Planktonic foraminifers and calcareous nannoplankton were used for dating of the Leg 40 cores wherever possible. For the zonal schemes applied, reference is made to Table 4 (Pleistocene - Oligocene), Table 5 (Eocene-Paleocene), and Table 6 (Mesozoic) in Chapter 1 of this volume. On these tables the zones are also correlated with absolute ages, series/periods (for the Tertiary), stages (for the Cretaceous), and the magnetic reversal sequence. The nannoplankton zones are as far as possible calibrated against the absolute age scale, but for the planktonic foraminifer zones the calibration has to be regarded as only approximate.

In some instances, where planktonic foraminifers and calcareous nannoplankton are absent or not sufficiently diagnostic, other fossil groups are used, such as palynomorphs for part of the Cretaceous of Site 361; radiolarians, palynomorphs, and fish denticles to identify the lower cores of Site 365 as Oligocene-Miocene.

A brief characterization of the Cenozoic and Mesozoic faunal and floral elements, their occurrence, and their stratigraphic significance in the individual sites is offered in the following. Figure 1 shows the ages for the individual cores of Sites 360-365 determined by biostratigraphic methods.

\section{CENOZOIC}

The dominant microfossils in the Tertiary of the Leg 40 sites are planktonic foraminifers and calcareous nannoplankton. Most of the biostratigraphic subdivisions in the individual sites are therefore based on these two fossil groups. Dissolution has affected the planktonic foraminiferal tests to various degrees. It was found to be lowest in the Walvis Ridge Site 363 and strongest in Sites 361 and 364 of the Cape Basin and Angola Basin, respectively. With few exceptions, benthic foraminifers are present in all sediments recovered. Compared with the planktonic foraminifers, however, they represent only a low percentage of the total foraminiferal fauna. The species distribution of the benthic foraminifers has been tabulated and tied in with the planktonic foraminifer and calcareous nannoplankton zones for the Paleogene of all sites and for the Neogene of Sites 360 and 362. No distinct species variation between the various sites resulting from latitudinal/temperature changes such as exist for the planktonic foraminifers was noted in the benthic assemblages.

The occurrence of siliceous microfossils such as radiolarians, diatoms, and silicoflagellates is very limited and erratic. Radiolarians occur frequently in Cores 1-13 


\begin{tabular}{|c|c|c|c|c|c|}
\hline \multicolumn{6}{|c|}{ CAPE BASIN } \\
\hline \multicolumn{3}{|c|}{ Site 360} & \multicolumn{3}{|c|}{ Site 361} \\
\hline Depth (m) & Core & Age & Depth $(m)$ & Core & Age \\
\hline $79.5-89.0$ & 1 & L Pliocene & $31.5-41.0$ & 1 & $\mathrm{U}$ \\
\hline $89.0-98.5$ & 2 & \multirow[b]{11}{*}{ Miocene } & $60.0-69.5$ & 2 & $\frac{2}{2}$ \\
\hline $98.5-108.0$ & 3 & & $98.0-107.5$ & 3 & $?$ \\
\hline 108.0-117.5 & 4 & & $136.0-145.5$ & $\begin{array}{l}4 \\
5\end{array}$ & M Eocene \\
\hline $\begin{array}{l}117.5-127.5 \\
127.5-136.5\end{array}$ & $\begin{array}{l}5 \\
6\end{array}$ & & $\begin{array}{l}174.0-183.5 \\
202.5-212.0\end{array}$ & $\begin{array}{l}5 \\
6\end{array}$ & $\mathrm{M}$ \\
\hline $136.5-146.0$ & 7 & & $231.0-240.5$ & 7 & $\mathrm{~L}$ \\
\hline $146.0-155.5$ & 8 & & $250.0-259.5$ & 8 & $\mathrm{~L}$ \\
\hline $155.5-165.0$ & 9 & & $259.5-269.0$ & 9 & UPaleocene \\
\hline $165.0-174.5$ & 10 & & $269.0-278.5$ & 10 & \\
\hline $174.5-184.0$ & 11 & & $278.5-288.0$ & 11 & $? \mathrm{~L}$ \\
\hline $184.0-193.5$ & 12 & & $297.5-307.0$ & 12 & \multirow{13}{*}{$\begin{array}{l}\text { Upper } \\
\text { Cretaceous } \\
\text { (or paly- } \\
\text { nomorphs) }\end{array}$} \\
\hline $193.5-203.0$ & 13 & & $326.0-335.5$ & 13 & \\
\hline $203.0-212.5$ & 14 & & $364.0-373.5$ & 14 & \\
\hline $212.5-222.0$ & 15 & $\mathrm{U}$ & $402.0-411.5$ & 15 & \\
\hline $222.0-231.5$ & 16 & $\mathrm{M}$ & $440.0-449.5$ & 16 & \\
\hline $231.5-241.0$ & 17 & \multirow{5}{*}{ M } & $478.0-487.5$ & 17 & \\
\hline $241.0-250.5$ & 18 & & $525.5-535.0$ & 18 & \\
\hline $260.0-269.5$ & 19 & & $573.0-582.5$ & 19 & \\
\hline $279.0-288.5$ & 20 & & $610.5-620.0$ & 20 & \\
\hline 298.0-307.5 & 21 & & $668.0-677.5$ & 21 & \\
\hline $317.0-326.5$ & 22 & \multirow[t]{2}{*}{$? \mathrm{M}$} & $715.5-725.0$ & 22 & \\
\hline $336.0-345.5$ & 23 & & $763.0-772.5$ & 23 & \\
\hline $355.0-364.5$ & 24 & \multirow[t]{2}{*}{ L } & $810.5-820.0$ & 24 & \\
\hline $374.0-383.5$ & 25 & & $858.0-867.5$ & 25 & Cretaceous s.l. \\
\hline $393.0-402.5$ & 26 & \multirow{3}{*}{ U } & $907.5-915.0$ & 26 & M-L Albian \\
\hline $412.0-421.5$ & 27 & & $953.0-962.5$ & 27 & \multirow{6}{*}{$\begin{array}{l}\text { L Albian } \\
\text { to } \\
\text { U Aptian } \\
\text { (on nannos) }\end{array}$} \\
\hline $431.0-440.5$ & 28 & & $1000.5-1010.0$ & 28 & \\
\hline $450.0-459.5$ & 29 & M & $1029.0-1038.5$ & 29 & \\
\hline $469.0-478.5$ & 30 & Oligocene & $1038.5-1048.0$ & 30 & \\
\hline $488.0-497.5$ & 31 & $\overline{\mathrm{M}}-\mathrm{L}$ & $1048.0-1057.5$ & 31 & \\
\hline $507.0-516.5$ & 32 & \multirow[b]{3}{*}{ L } & $1057.5-1067.0$ & 32 & \\
\hline $526.0-535.5$ & 33 & & $1067.0-1076.5$ & 33 & \multirow{5}{*}{ ? L } \\
\hline $545.0-554.5$ & 34 & & $1076.5-1086.0$ & 34 & \\
\hline $564.0-573.5$ & 35 & \multirow{6}{*}{ U } & $1086.0-1095.5$ & 35 & \\
\hline $573.5-583.0$ & 36 & & $1095.5-1105.0$ & 36 & \\
\hline $592.5-602.0$ & 37 & & $1105.0-1114.5$ & 37 & \\
\hline $611.5-621.0$ & 38 & & $1114.5-1124.0$ & 38 & $? 2$ \\
\hline $630.5-640.0$ & 39 & & $1124.0-1133.5$ & 39 & \multirow{9}{*}{$\begin{array}{l}\text { Aptian } \\
\text { (on nannos) }\end{array}$} \\
\hline $6495-659.0$ & 40 & & $1143.0-1152.5$ & 40 & \\
\hline $668.5-678,0$ & 41 & $\mathrm{U}-\mathrm{M}$ & $1162.0-1171.5$ & 41 & \\
\hline $678.0-687.5$ & 42 & \multirow{9}{*}{ Eocene } & $1181.0-1190.5$ & 42 & \\
\hline $697.0-706.5$ & 43 & & $1200.0-1209.5$ & 43 & \\
\hline $716.0-725.5$ & 44 & & $1219.0-1228.5$ & 44 & \\
\hline $735.0-744.5$ & 45 & & $1238.0-1247.5$ & 45 & \\
\hline $754.0-763.5$ & 46 & & $1257.0-1266.5$ & 46 & \\
\hline $773.0-782.5$ & 47 & & $1266.5-1276.0$ & 47 & \\
\hline $792.0-801.5$ & 48 & & $1285.5-1295.0$ & 48 & $? \mathrm{~L}$ \\
\hline $811.0-820.5$ & 49 & & $1304.5-1314.0$ & 49 & \\
\hline $830.0-839.5$ & 50 & & & & \\
\hline
\end{tabular}

Figure 1. Age of cores recovered from Sites 360-365.

(lower Pliocene to upper Miocene) of Site 360. They are common in the Pleistocene to upper Pliocene in Cores 1 to 7 of Site 362 and infrequent in the middle Pliocene to upper Miocene Cores 8 to 26 of that site. Cores 1 to 26 of Site 362 also yielded a rich and diverse diatom flora, which in Cores 7 and 17 includes fresh-water assemblages. Radiolarians helped to date Core 6 of Site 364 as middle Oligocene. They were the only microfossils present in that core. Radiolarians, together with palynomorphs, were also instrumental in dating the lowermost Core 7 of Site 365 as younger Tertiary. Silicoflagellates are common to rare in the Pleistocene-Pliocene Cores 1 to 14 of Site 362. Tertiary palynomorphs (pollen, spores) were investigated in Site 365 with the purpose of dating Cores 4 to 7 which are void of diagnostic calcareous microfossils. Ichthyoliths were investigated in the Paleocene and Upper Cretaceous Site 361 and in Cores 4 to 7 of the Angola Basin Site 365, indicating an upper Tertiary age for this interval, the same as do the radiolarians and palynomorphs. Ostracodes were found to be present in many of the investigated Tertiary samples but as a rule they occur in only very small numbers and therefore were not studied for the Initial Report volume.

\begin{tabular}{|c|c|c|c|c|c|}
\hline \multicolumn{6}{|c|}{ WALVIS RIDGE } \\
\hline \multicolumn{3}{|c|}{ Site $362 / 362 \mathrm{~A}$} & \multicolumn{3}{|c|}{ Site 363} \\
\hline Depth (m) & Core & Age & Depth (m) & Core & Age \\
\hline \multirow{43}{*}{\begin{tabular}{|c|}
$36.0-45.5$ \\
$45.5-55.0$ \\
$55.0-64.5$ \\
$64.5-74.0$ \\
$74.0-83.5$ \\
$83.5-93.0$ \\
$93.0-102.5$ \\
$102.5-112.0$ \\
$112.0-121.5$ \\
$121.5-131.0$ \\
$131.0-140.5$ \\
$140.5-150.0$ \\
$150.0-159.5$ \\
$159.5-169.0$ \\
$178.5-188.0$ \\
$197.5-207.0$ \\
$216.5-226.0$ \\
$235.5-245.0$ \\
$254.5-264.0$ \\
$273.5-283.0$ \\
$292.5-302.0$ \\
$311.5-321.0$ \\
$330.5-340.0$ \\
$349.5-359.0$ \\
$368.5-378.0$ \\
$387.5-397.0$ \\
$406.5-416.0$ \\
$425.5-435.0$ \\
$444.5-454.0$ \\
463.5473 .0 \\
$482.5-492.0$ \\
$501.5-511.0$ \\
$520.5-530.5$ \\
$543.0-558.5$ \\
$577.5-587.0$ \\
$596.5-606.0$ \\
$615.5-625.0$ \\
$644.0-653.5$ \\
$672.5-687.0$ \\
$701.5-710.5$ \\
$729.5-739.0$ \\
$758.0-767.5$ \\
$786.5-796.0$ \\
$796.0-805.5$ \\
\end{tabular}} & \multirow{43}{*}{$\begin{array}{r}1 \\
2 \\
3 \\
4 \\
5 \\
6 \\
7 \\
8 \\
9 \\
10 \\
11 \\
12 \\
13 \\
14 \\
15 \\
16 \\
17 \\
18\end{array}$} & Pleistocene & \multirow{40}{*}{\begin{tabular}{|c|}
$31.0-40.5$ \\
$50.0-59.5$ \\
$69.0-78.5$ \\
$88.0-97.5$ \\
$107.0-116.5$ \\
$126.0-135.5$ \\
$145.0-154.5$ \\
$164.0-173.5$ \\
$183.0-192.5$ \\
$202.0-211.5$ \\
$221.0-230.5$ \\
$240.0-249.5$ \\
$259.0-268.5$ \\
$278.0-287.5$ \\
$297.5-306.0$ \\
$306.5-316.0$ \\
$316.0-325.5$ \\
$325.5-335.0$ \\
$335.0-344.5$ \\
$344.5-354.0$ \\
$363.5-373.0$ \\
$373.0-382.5$ \\
$382.5-392.0$ \\
$401.5-411.0$ \\
$420.5-430.0$ \\
$439.5-449.0$ \\
$458.5-468.0$ \\
$477.5-487.0$ \\
$496.5-506.0$ \\
$515.5-525.0$ \\
$534.5-544.0$ \\
$553.5-563.0$ \\
$572.5-582.0$ \\
$591.5-601.0$ \\
$610.5-620.0$ \\
$629.5-639.0$ \\
$648.5-658.0$ \\
$667.5-677.0$ \\
$686.5-696.0$ \\
$705.5-715.0$ \\
\end{tabular}} & \multirow{40}{*}{$\begin{array}{l}1 \\
2 \\
3 \\
4 \\
5 \\
6 \\
7 \\
8 \\
9 \\
10 \\
11 \\
12 \\
13 \\
14 \\
15 \\
16 \\
17 \\
18 \\
19 \\
20 \\
21 \\
22 \\
23 \\
24 \\
25 \\
26 \\
27 \\
28 \\
29 \\
30 \\
31 \\
32 \\
33 \\
34 \\
35 \\
36 \\
37 \\
38 \\
39 \\
40\end{array}$} & U-L Miocene \\
\hline & & \multirow{6}{*}{$\begin{array}{l}\text { Pleistocene } \\
\text { or } \\
\text { U. Pliocene }\end{array}$} & & & \\
\hline & & & & & U-M \\
\hline & & & & & 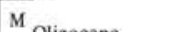 \\
\hline & & & & & Oligocene \\
\hline & & & & & \\
\hline & & & & & L \\
\hline & & Pleistocene & & & L \\
\hline & & & & & \\
\hline & & M Pliocene & & & Mे \\
\hline & & UPliocene & & & $\mathrm{MN}$ \\
\hline & & & & & Eocene \\
\hline & & L Pliocene & & & \\
\hline & & L. Pliocene & & & \\
\hline & & & & & $\mathrm{U}$ \\
\hline & & & & & M Paleocene \\
\hline & & & & & $\frac{M}{L}$ Paleocene \\
\hline & & & & & $\mathrm{U}$ \\
\hline & & & & & \\
\hline & & & & & M Maestrichtian \\
\hline & & U & & & \\
\hline & & & & & \\
\hline & & & & & Campanian \\
\hline & & & & & \\
\hline & & & & & L Sant.-U Coniac. \\
\hline & & Miocene & & & \\
\hline & & & & & \\
\hline & & & & & \\
\hline & & - & & & \\
\hline & & & & & \\
\hline & & M & & & Albian* \\
\hline & & & & & \\
\hline & & & & & \\
\hline & & & & & \\
\hline & & M & & & \\
\hline & & $\mathrm{L}$ & & & M \\
\hline & & & & & L \\
\hline & & $\mathrm{L}$ & & & \\
\hline & & & & & L Alb.-U Apt. \\
\hline & & LMiocene & & & UAptian \\
\hline & & to & \multirow{14}{*}{\multicolumn{3}{|c|}{$\begin{array}{l}\text { Albian ages given for Site } 363 \text { cores } \\
26-38 \text { are based on calcareous nanno- } \\
\text { plankton. On planktonic foraminifers } \\
\text { they are: Cores } 26-29 \text { - U-M Albian, } \\
30-\text { M-L Albian, } 31-38 \text { - basal Albian- } \\
\text { U Aptian. }\end{array}$}} \\
\hline & & U Oligocene & & & \\
\hline & & U Otigocene & & & \\
\hline \multicolumn{3}{|c|}{ HOLE A } & & & \\
\hline \multirow{10}{*}{\begin{tabular}{|c|}
$696.0-701.0$ \\
$796.0-805.5$ \\
$824.0-843.5$ \\
$872.0-881.5$ \\
$910.0-919.5$ \\
$929.0-938.5$ \\
$948.0-957.5$ \\
$967.0-976.5$ \\
$995.5-1000.5$ \\
$1024.0-1033.5$ \\
$1062.0-1071.5$ \\
$1071.5-1081.0$
\end{tabular}} & \multirow{10}{*}{$\begin{array}{r}1 \\
2 \\
3 \\
4 \\
5 \\
6 \\
7 \\
8 \\
9 \\
10 \\
11 \\
12 \\
\end{array}$} & L. Miocene & & & \\
\hline & & $\mathrm{U} \cdot \mathrm{M}$ & & & \\
\hline & & M Oligocene & & & \\
\hline & & $\bar{M}-\mathrm{L}$ & & & \\
\hline & & $\mathrm{L}$ & & & \\
\hline & & $\mathrm{U}$ & & & \\
\hline & & Eocene & & & \\
\hline & & & & & \\
\hline & & $\sqrt{\mathrm{L}}$ & & & \\
\hline & & & & & \\
\hline
\end{tabular}

Figure 1. (Continued).

\section{Site 360}

In the Cape Basin Site 360, the Miocene to middle Eocene planktonic foraminiferal assemblages show a strong boreal, Austral-New Zealand character. However, warmer water forms are often also present, thus allowing for a correlation of the tropical and boreal planktonic foraminiferal zonal schemes.

\section{Site 361}

The middle Eocene to lower Paleocene Cores 1 to 11 of Site 361 slightly overlap the Site 360 stratigraphic sequence. Compared with planktonic foraminifers of Site 360 , those of Site 361 are of poor preservation, often infrequent, or may even be totally dissolved as a result of deeper deposition. Fortunately, the calcareous nannoplankton is somewhat better preserved. Consequently most of the Eocene and Paleocene of Site 361 could be zoned on this fossil group. 


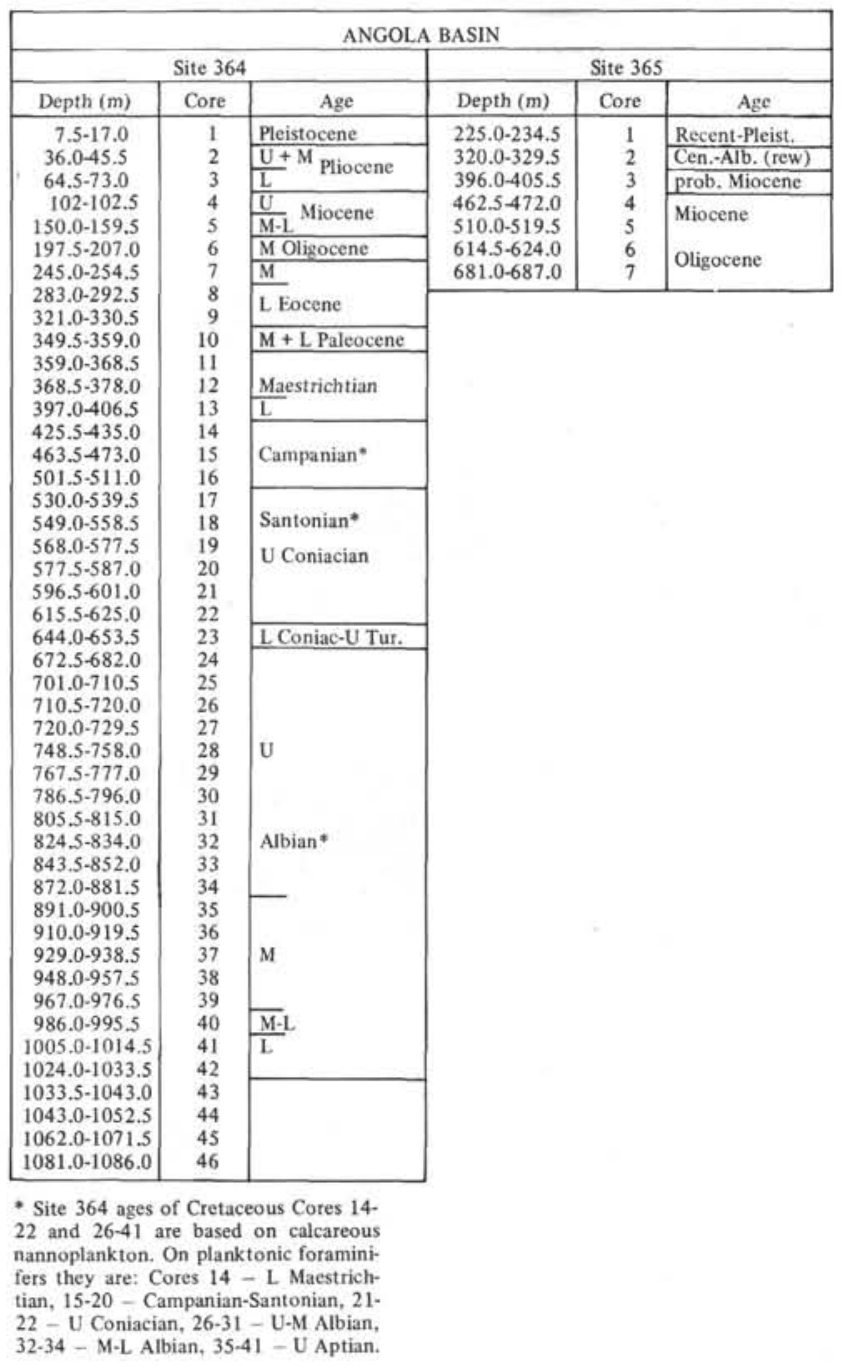

Figure 1. (Continued).

\section{Sites $362 / 362 A$ and 363}

Site 362/362A on Walvis Ridge penetrated a stratigraphic sequence similar to the Cape Basin Site 360 (Pleistocene to the upper part of the lower Eocene). The sequence is also characterized by a comparable faunal/floral association. However, the boreal/tropical species ratio and the number of specimens present in each fossil group shifts in the Walvis Ridge site towards more warm-water forms. Both boreal and tropical zonal schemes are consequently applied to the Site 362 Neogene. In the Paleogene of Site $362 \mathrm{~A}$, on the other hand, where warm-water forms dominate, the tropical zonal scheme alone could be used. This implies a progressive cooling throughout the Tertiary, becoming more and more pronounced during the Neogene.

From its tropical latitudinal position of $19^{\circ} 45^{\prime}$ one would expect Site 362 to be dominated much more by warm-water foraminifers, particularly so in the Pliocene-Pleistocene. This is not the case because colder water masses from the Cape Basin still reach the crest and the northern slopes of Walvis Ridge. The change from the southern mixed boreal/tropical planktonic foraminiferal faunas as still present in Site 362 and to those dominated by tropical D rapidly over a short distance on the northern slope of the Walvis Ridge. Site 363 , at a latitude of $19^{\circ} 39^{\prime} \mathrm{S}$, only slightly further to the north than Site 362 , is already characterized by a much higher percentage of warm-water planktonic foraminifers. Unfortunately, the Neogene at this site only measures about 50 meters and was poorly cored, therefore limiting close comparisons. The Paleogene of Site $362 \mathrm{~A}$ with its almost continuous sequence of planktonic foraminiferal and calcareous nannoplankton zones, on the other hand, contains a tropical fauna. Even so, however, it still contains some elements that point towards a somewhat more temperate environment.

The two Walvis Ridge sites, 362 and 363, are too close together and in part were not cored continuously enough to shed sufficient light on the north-south extensions and limits of boreal and tropical planktonic foraminiferal taxa through Paleocene and Neogene time. Thus, they do not yet fully answer the question to what degree the Walvis Ridge acted as a limiting factor to the north-south extension of cold- and warm-water planktonic foraminiferal faunas during this interval. A series of holes from the northern part of the Cape Basin, across Walvis Ridge and into the southern Angola Basin would be required to provide a more complete answer.

\section{Site 364}

The Neogene and Paleogene planktonic foraminiferal faunas of the Angola Basin Site 364 at latitude $11^{\circ} 34^{\prime} \mathrm{S}$, the northernmost of Leg 40, are of fully tropical character. With typical Pliocene forms such as Globorotalia multicamerata, $G$. miocenica, and $G$. exilis present here, but not in the Walvis Ridge sites, it is noteworthy that Globorotalia tumida tumida, one of the planktonic foraminiferal species most restricted to tropical latitudes, was not recorded from the Pliocene-Pleistocene of Site 364. This could be an indication that the upper layers of the Angola Basin water mass remain until the present day under the influence of some colder southern currents.

\section{Site 365}

The greenish gray mudstones with fine sandy layers in the Angola Basin Site 365, Cores 4 to 7, are characterized by a Tertiary faunal/floral association that does not occur in any other Leg 40 sediment of similar age. The interval is characterized by the virtual absence of calcareous microfossils. Instead, the sediments carry a fairly rich arenaceous foraminiferal fauna consisting predominantly of Bathysiphon specimens, other primitive arenaceous species, and rare Cyclammina. Such an association combined with the absence of calcareous forms points to a deposition level below the lysocline. The arenaceous foraminiferal faunas are accompanied by palynomorphs, ichthyoliths, and, in isolated levels, by pyritized radiolarians. They all are of Oligocene-Miocene age and thus prove that the Cretaceous foraminifers and calcareous nannoplankton in the overlying Cores 1 to 3 are not in situ.

\section{CRETACEOUS}

The Cretaceous section of the Cape Basin Site 361 differs in its faunal and floral content markedly from those of the Walvis Ridge Site 363 and the Angola Basin Site 364. The 
non-calcareous clays of the Upper Cretaceous and the sapropels of the Lower Cretaceous of Site 361 are virtually void of foraminifers and an impoverished calcareous nannoplankton flora is restricted to the Lower Cretaceous. Palynomorphs, on the other hand, are frequent almost throughout the section and, together with the sparse calcareous nannoplankton, have allowed us to date the Site 361 Cretaceous sediments at least in a tentative manner.

The Cretaceous of Sites 363 and 364 on the other hand with few exceptions contain distinct planktonic and benthic foraminiferal faunas and calcareous nannoplankton floras on which the more accurate age determinations of the sediments of these two sites are based. Of some stratigraphic significance here are a number of ammonites recovered from the Lower Cretaceous of both sections and palynomorphs studied for Site 364 .

\section{Site 361}

The Cretaceous Cores 12 to 49 of the Cape Basin Site 361 almost exclusively consist of non-calcareous clays and sapropels. With very few exceptions calcareous foraminifers are absent. Dwarfed and rare deep-water arenaceous foraminifers are restricted to Cores 20 to 28 . Calcareous nannoplankton, though present in most samples of the lower part of the interval, are usually poor in numbers and preservation. However they allow for age dating and zonal subdivision for Cores 26 to 49 .

The absence of diagnostic foraminifers and in part also of calcareous nannoplankton in the Cretaceous of Site 361 is to some degree compensated by an almost continuous presence (except for Cores 25 and 26) of palynomorphs. These include pollen, spores, and dinoflagellates. They largely confirm the ages indicated by the calcareous nannoplankton. Also present are wood fragments and cuticles, which are very frequent in the sapropels of Cores 27 to 49 . The largest wood fragment recovered from the cores measures $8 \mathrm{~cm}$ in length. Conifers and cycadeoids dominate. They belong to the same flora that lived in the general area before the opening of the South Atlantic: Patagonia, Tico in southern South America, Grahamland in Antarctica, and Uitenhage in South Africa.

\section{Sites 363 and 364}

The Upper and Lower Cretaceous of the Walvis Ridge Site 363, Cores 18 to 40 and the Angola Basin Site 364, Cores 11 to 46 , mostly contains rich calcareous nannoplankton floras and planktonic and benthic foraminiferal faunas. Dissolution effects in certain parts of the sections (Cores 22-25 in Site 363, Cores 11-12, 15-20, and 42-46 in Site 364) have partially or completely destroyed the planktonic foraminiferal components, and in part also affected the preservation of the calcareous nannoplankton.

Radiolarians are more frequent in Site 363 than in Site 364. They are particularly rich in the dissolution facies where most of the planktonic foraminifers have been dissolved. The radiolarians are mostly of poor preservation and consequently of little stratigraphic significance.

Palynomorphs (pollen, spores, dinoflagellates) were found to be frequent and age-diagnostic in the sapropelic sediments of Site 364 where they have been studied in some detail for this volume. The Cretaceous of Site 363 on
Walvis Ridge, on the other hand, has not been investigated for palynomorphs.

Of special stratigraphic interest is the presence of a number of ammonite species in the Lower Cretaceous of Sites 363 and 364, where their occurrences could be tied in with the calcareous nannoplankton and planktonic foraminiferal zonal schemes. Rare Inoceramus specimens were found in the Upper Cretaceous of the Cape Basin Site 361 and more frequently in the Lower Cretaceous of the Angola Basin Site 364.

Ostracodes occur in many of the Site 363 and 364 Cretaceous samples investigated. As in the Tertiary they were as a rule found to be scarce and therefore were not studied for this volume.

Calcisphaerulidae occur in Sites 361, 363, and 364. From DSDP cores they were for the first time described from Jurassic and Cretaceous sediments recovered during Leg 27 in the eastern Indian Ocean, and later from the Paleocene during the Antarctic Leg 35. They are present in small numbers only in the Lower Cretaceous of Site 361, and in the Cretaceous of Site 364 . In Site 363 they are usually rare in the lower Paleocene and Maestrichtian-Campanian, but occur mostly in floods in the Albian-Aptian. Several species of the genus Pithonella and one of the genus Bonetocardiella could be distinguished, most apparently restricted stratigraphically.

Both the planktonic and benthic Aptian-Albian foraminifers are of a boreal Austral type such as known from the southern Indian Ocean and Australia. In the planktonic foraminifers this is expressed by a strong predominance of small sized hedbergellid forms and the absence of more highly evolved index forms such as known from the Tethyan realm.

Several contributors of paleontological papers to this volume, in addition to analyzing faunas and floras, plotting their distribution and giving age assignments, also discuss environmental aspects. This includes in particular water temperature and depth of deposition, and the opening of the South Atlantic towards the North Atlantic. Conclusions are not always in agreement. While on foraminifers, planktonics and benthics, the opening is postulated to have taken place not earlier than Cenomanian or Turonian. Ammonite evidence indicates that this event may have taken place earlier, and was already in existence in the middle Albian.

The fact that foraminiferal associations of Sites 363 and 364 differ slightly is attributed more to local than to overall environmental conditions. The conclusions on the depth of deposition at both sites range from fairly shallow to moderately deep. Using the Upper Cretaceous benthic foraminifers, for instance, it is estimated to be between the shelf edge and the deeper part of the slope, or between about 200 and 2000 meters.

A significant result is the apparent absence of Cenomanian and Turonian microfaunas in the Walvis Ridge Site 363 and of Cenomanian and lower Turonian ones in the Angola Basin Site 364, indicating a considerable and widespread hiatus, cutting out a considerable part of the Cretaceous section. A few Cenomanian planktonic foraminifers, however, were found in reworked or redeposited sediments of Site 365 . They imply that sedimentation during the Cenomanian must have taken 
place at least in parts of the Angola Basin. Further, this Cenomanian fauna is of Tethyan character (Rotalipora appeninnica) and thus supports the contention that the connection to the north was already in existence at that time.

While good agreement exists at all Leg 40 sites on the correlation of the Tertiary and Upper Cretaceous planktonic foraminiferal and calcareous nannoplankton zonal schemes with regard to ages and stages, there remain some discrepancies still to be resolved in the Albian and Aptian.

At both Sites 363 and 364 the Aptian/Albian boundary based on calcareous nannoplankton evidence is about 150 meters above that on planktonic foraminifers. Ages given by the ammonites are in better agreement at both sites with the nannoplankton dating. The same is true in comparison with the palynomorphs of Site 364 , which, like the calcareous nannoplankton, do not contain recognized Aptian forms. The age assignments based on the benthic foraminifers are virtually identical with those of the planktonic forms. Those of the radiolarians are not of comparable accuracy and therefore do not help to resolve existing problems in the correlation of zonal schemes and stages.

The discrepancy in the correlation of Cretaceous stages based on calcareous nannoplankton and planktonic foraminifers, respectively, is largely a question of calibration. The index species present in the Lower Cretaceous calcareous nannoplankton of Sites 363 and 364 permit the application of the zonal scheme that is tied to the classical stages in southern France. On the other hand index species are mostly absent or are only very indistinctly present among the Lower Cretaceous boreal planktonic foraminifers of these two sites. The planktonic foraminiferal zonal scheme based on Tethyan species therefore could not or could only tentatively be applied. Before more accurate correlations with stages and zonal schemes based on other fossil groups can be realized, it is necessary that the distribution and significance of the boreal planktonic foraminiferal species become better known and tied more reliably with those of the Tethys, on which the present standard zonal scheme is based. 